\title{
Morphometry and morphological analysis of carotico-clinoid foramen: an anatomical study with clinical implications
}

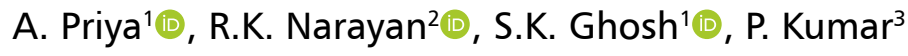 \\ ${ }^{1}$ Department of Anatomy, All India Institute of Medical Sciences, Patna, India \\ ${ }^{2}$ Department of Anatomy, Andaman and Nicobar Islands Institute of Medical Sciences, Port Blair, India \\ ${ }^{3}$ Department of Radiodiagnosis, All India Institute of Medical Sciences, Patna, India
}

[Received: 13 October 2021; Accepted: 29 October 2021; Early publication date: 16 November 2021]

Background: The dural fold between anterior and middle clinoid processes on mineralisation leads to the formation of caroticoclinoid foramen (CCF). Different morphology of this foramen presents with different clinical features. The present study reports the frequency of CCF in the population of Bihar, while providing an account of assimilated information from previous literature regarding the association of caroticoclinoid ligament ossification with age and human genetics. Materials and methods: The study was conducted on 100 adult dry human skulls of unknown age and sex, and 50 lateral view radiographs of the head.

Results: Of the 100 dry skull bones, 9 presented with different forms of CCF. Bilateral complete foramina were noticed in $2(2 \%)$ skull bones, while the incomplete foramina were observed bilaterally in $3(3 \%)$ and unilaterally in 4 (4\%) skulls. The lateral view radiograph data $(n=50)$ presented with a bilateral foramen in one subject and unilateral complete CCF in two different subjects. On measurements of the diameters of the complete CCF the mean values observed were $4.06 \mathrm{~mm}$ and $4.51 \mathrm{~mm}$ on the right side, while that on the left side were $5.15 \mathrm{~mm}$ and $4.14 \mathrm{~mm}$. For the incomplete foramina, the mean values for the vertical diameter were $4.48 \mathrm{~mm}$ on the right and $4.19 \mathrm{~mm}$ on the left side, respectively.

Conclusions: The frequency of CCF in the present study population of Bihar was much lesser than that of previously studied populations. However, the variation in frequency of different morphological types of CCF was observed to be the same across populations. The variations in CCF's metric data could help in predicting the morphological changes it causes to the clinoidal segment of the internal carotid artery, as well as in distinguishing its varieties. (Folia Morphol 2023; 82, 1: 108-118)

Key words: caroticoclinoid foramen, human genetics, mineralisation

\section{INTRODUCTION}

Henle [see 20] was the first to describe the caroticoclinoid foramen (CCF) formed by the presence of an osseous bridge between the tip of the middle and anterior clinoid processes (Fig. 1A). The anterior clinoid process (ACP) is prolongation of medial end of lesser wing of sphenoid, whereas the middle clinoid process (MCP) is present on either side of the tuberculum sellae. The dural fold between ACP and MCP (also called as caroticoclinoid ligament [CCL])

Address for correspondence: Dr. R.K. Narayan, Assistant Professor, Department of Anatomy, Andaman and Nicobar Islands Institute of Medical Sciences, Port Blair, India, tel: 9234896343, e-mail: narayanintouch@gmail.com

This article is available in open access under Creative Common Attribution-Non-Commercial-No Derivatives 4.0 International (CC BY-NC-ND 4.0) license, allowing to download articles and share them with others as long as they credit the authors and the publisher, but without permission to change them in any way or use them commercially. 

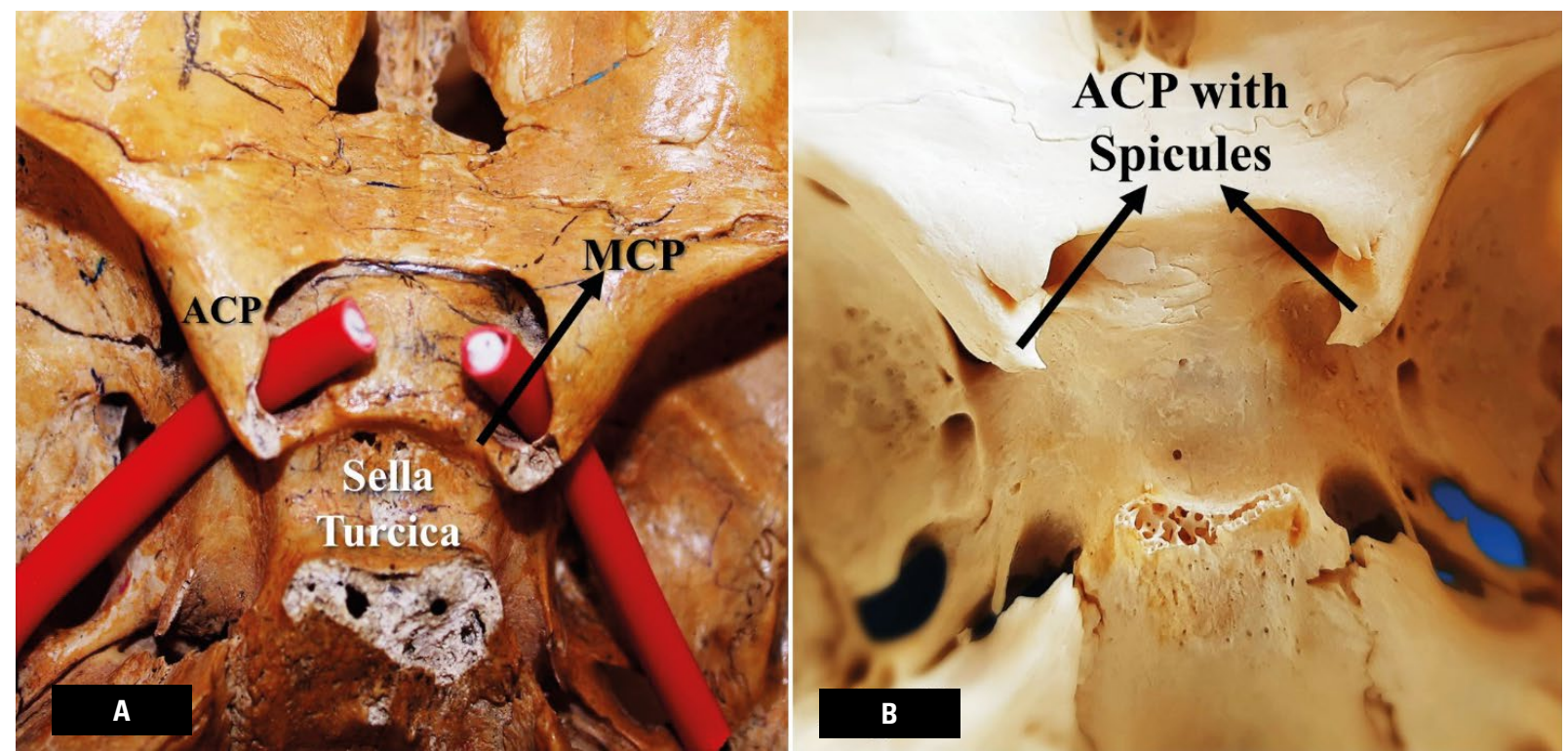

Figure 1. A. Specimen of skull base showing sella turcica and bilateral complete caroticoclinoid foramen (CCF) formed between anterior clinoid process (ACP) and middle clinoid process (MCP). Red coloured polyvinyl chloride wire inserted in the CCFs used to measure the diameter of the foramen; B. Specimen of skull base showing sella turcica and bilateral incomplete CCF with spicules extending from ACP.

on ossification leads to the formation of CCF, while the ossified fold between ACP and posterior clinoid process (PCP) (also known as interclinoid ligament $[\mathrm{ICL}]$ ) is termed as the "sella turcica bridge" (STB) and forms the interclinoid foramen (ICF) $[5,47]$.

The literature mentions multiple classification by different authors regarding the morphology (complete, contact, and incomplete [with or without spicules] types) of CCF. Different morphological patterns of the foramen present with different clinical features. The complete foramen (Fig. 1A) can present with severe headache due to compression and spontaneous rupture of the clinoidal segment of internal carotid artery (ICA) [47]. Incomplete CCF (Fig. 1B) can further be classified into contact type and one with spicules on ACP or MCP. The latter can cause rupture of ICA and may lead to the formation of carotico-cavernous sinus fistula, a direct communication between the ICA and cavernous sinus $[5,21]$. The varied clinical presentations raise the query related to the aetiopathogenesis of the foramen, which indeed is related to the ossification of the dural fold or the ligament.

Mineralisation or ossification physiologically occurs in two types of human tissue, the bone, and tooth. Occurrence of ossification in other tissues is referred to as ectopic calcification. Touska et al. [55] mentioned that ectopic calcification or mineralisation of skull base ligaments occurs later in life as a result of interaction between many factors, including genetic, mechanical stress, and metabolic [55]. Ossified skull base ligaments have been reported in different age groups, but when observed in children without any evident stimuli as mentioned above may explain the embryological basis, termed as atavistic (i.e., representing evolutionary remnants), on account of the presence of similar ossified structures in non-human species [11].

Since being explained by Henle [see 20], numerous populations based radiographic, autopsy and dry skull bone studies have reported the frequency of $\mathrm{CCF}$, while trying to explain few aetiological associations with age and diseases. None of these findings were reproduced in following studies till date. The present study while reporting the frequency of CCF in the population of Bihar, also provides an account of assimilated information from previous literature regarding the association of frequency of CCF with age and human genetics.

\section{MATERIALS AND METHODS}

The multicentric retrospective study was conducted on 100 adult dry human skulls of unknown age and sex, and 50 lateral view radiographs of the head. The present study was done in Department of Anatomy at All India Institute of Medical Sciences, Patna while dry skull bone data were also collected from other major medical institutes of Bihar. The radiological data of those patients whose lateral view of head 

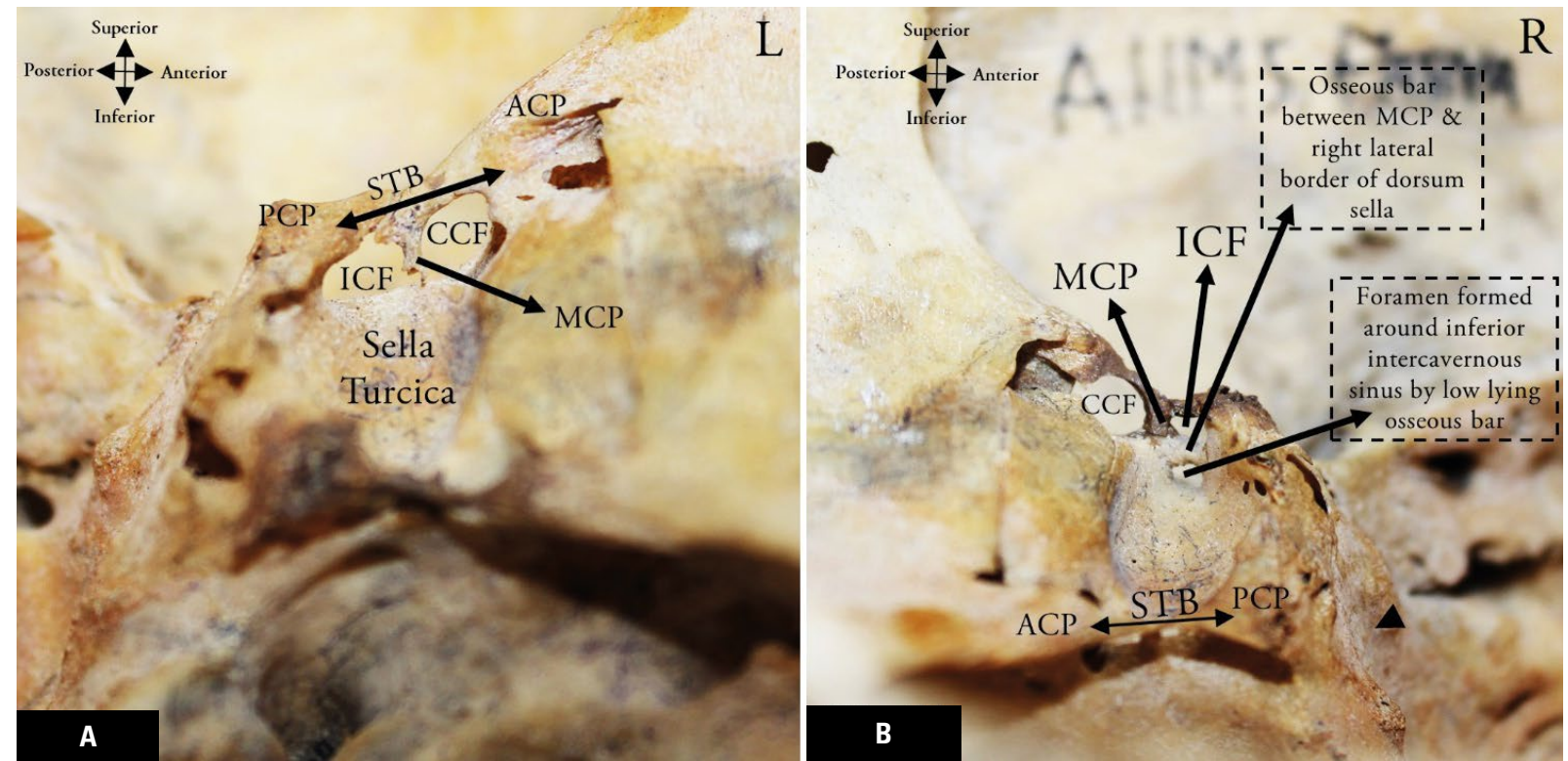

Figure 2. A. Specimen of skull base showing left side of the sella turcica. Sella turcica bridge (STB) is formed by the ossified connection between anterior clinoid process (ACP), middle clinoid process (MCP), and posterior clinoid process (PCP). Caroticoclinoid foramen (CCF) formed underneath the ossified segment connecting ACP and MCP, housing the internal carotid artery. Interclinoid foramen (ICF) formed underneath the segment connecting MCP and PCP; B. Right side of the sella turcica in a skull base specimen showing STB, ACP, MCP, PCP, CCF, and ICF. The unique feature of a low lying osseous bar connecting MCP and right lateral border of dorsum sella, theoretically, forming a foramen around the inferior intercavernous sinus; $L$ — left; $R$ - right.

was taken for non-cranial pathologies were collected from archives of Department of Radiodiagnosis at All India Institute of Medical Sciences, Patna. Prior approval from ethics committee of the above mentioned institute was taken to conduct the study, and the requirement of the informed patient consent for utilising stored radiographic data from the departmental archives was waived off.

The following parameters were observed:

- presence or absence of CCF;

- type of foramen (complete/incomplete, unilateral/ /bilateral);

- shape of the CCF, if present;

- antero-posterior diameter and vertical diameter of CCF, if present.

All the above parameters were observed in dry skull bones, while in the radiographs only the first two parameters were noted. In addition, the frequency of the coexisted ossified variants of the ICF (foramen formed by ossification of STB between ACP-PCP and that formed by ossification of interclinoid ligament between MCP-PCP) were also observed on the dry skull and radiographic specimens. In the radiological data, age, and gender wise frequency for CCF was observed.

The present study comprised of skulls in which the vaults were removed so that the upper surface of sphenoid bone could be visualised. Skulls with broken sphenoid bone were excluded. The dry skull specimens without any visible deformity in upper surface of sphenoid bone were included. All observations and measurements were taken twice, independently by two observers. Mean value of the measurements by the two observers were taken as the accurate value for each parameter.

Probes of known dimensions (Polyvinylchloride Wire of known calibrated diameter of $5.5 \mathrm{~mm}$ ) were used to measure the diameter of the CCF. Measurements were also recorded in millimetres $(\mathrm{mm})$ using Mitutoyo digital vernier callipers (precision $0.01 \mathrm{~mm}$; Kawasaki, Japan).

\section{RESULTS}

Of the 100 dry skull bones, 9 presented with different forms of CCF. Bilateral complete foramina (Fig. 1A) were noticed in two skull bones, while the incomplete foramina (Fig. 1B) were observed bilaterally in 3 , and unilaterally in 4 skulls of which 3 were on the left and one was on the right side.

One of the skulls with bilateral CCF also presented with the "sella turcica bridge" joining the ACP, MCP, and PCP bilaterally (Fig. 2A, B). On the left side, the bridge formed the CCF between the ACP and MCP, while a contact type ICF was formed between MCP and PCP having a thin gap between the extensions 


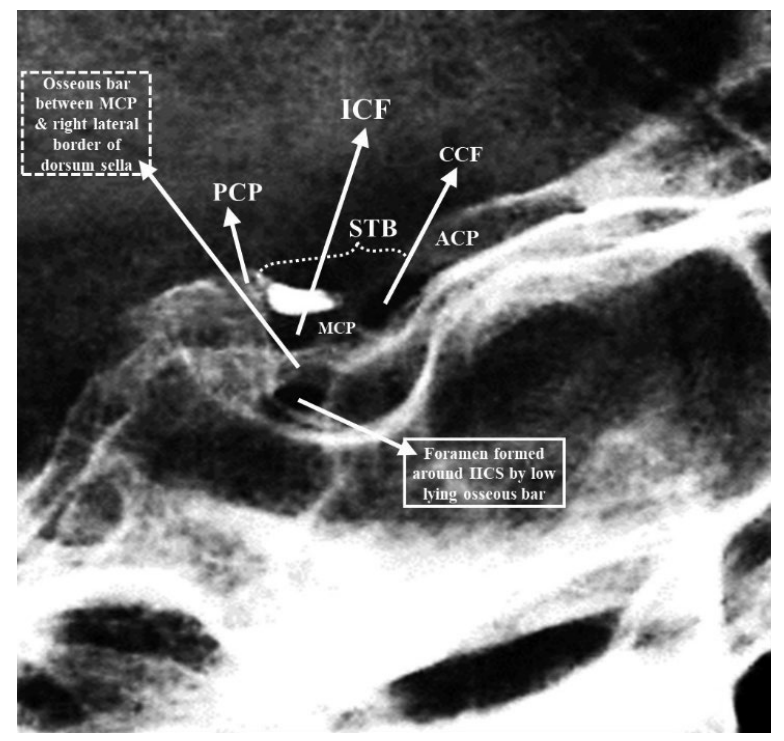

Figure 3. Radiograph of right lateral view of the skull base specimen presenting with sella turcica bridge (STB), anterior clinoid process (ACP), middle clinoid process (MCP), posterior clinoid process (PCP), caroticoclinoid foramen (CCF), interclinoid foramen (ICF), and a foramen around the inferior intercavernous sinus formed by a low-lying osseous bar connecting MCP and right lateral border of dorsum sella; IICS — inferior inter-cavernous sinus.

of the two processes towards each other respectively (Fig. 2A). On the right side of the sella turcica, the bridge forms a CCF and the ICF. The ICF was divided into two foramina by an osseous bar between the MCP and the midpoint of the right lateral border of the dorsum sella (Fig. 2B). The right lateral radiographic view of the concerned skull also confirmed the ossification of the bridge and the osseous bar (Fig. 3). The second specimen presenting with bilateral CCF had no "sella turcica bridge"; therefore, the ICF was also absent (Fig. 1A).

Among the dry bone specimens having incomplete foramina ( $n=7)$, an extension from the ACP was observed which was distant from the prominent MCP. In three of these specimens, the extensions from the ACP were in the form of pointed spicule, which can be classified as type III (dangerous type) CCF, based on Keyes classification.

On measurements of the antero-posterior and vertical diameter of the complete CCF, the mean values observed were $4.06 \mathrm{~mm}$ and $4.51 \mathrm{~mm}$ on the right side while that on the left side were $5.15 \mathrm{~mm}$ and $4.14 \mathrm{~mm}$. For the incomplete foramina, the mean values for the vertical diameter were $4.48 \mathrm{~mm}$ on the right and $4.19 \mathrm{~mm}$ on the left side, respectively.

The lateral view radiograph data $(n=50)$ presented with one bilateral and two unilateral complete
CCF. The sample comprised of 25 radiographs from each gender with an age range of 12 to 73 years. The bilateral complete CCF was observed in a 43-yearold male, while the unilateral incomplete ones were observed on the right lateral view radiograph of a 27-year-old male, and a 17-year-old female.

\section{DISCUSSION}

The dural folds or the ligamentous structures (CCL) extending between the ACP and MCP on ossification leads to the formation of CCF. The total frequency of CCF in the present study population of Bihar (9\%) though varies differently with individual reports of certain population, but when compared to the total reported values of those populations, it is on the lesser side to that of the Caucasian (25.9\%), Turkish (20.51\%), South Indian (21.06\%) and Gujrat region (12.5\%) populations (Table 1) [1, 4-7, 9, 15, 18-20, $31,33,35,37,45,48-51,53]$. The frequency of CCF is more in Caucasian and Turkish population as compared to the oriental population, which could be explained on the basis of racial differences. Similar patterns were observed when the frequency of CCF was observed in the present study based on the morphological classification given by Keyes [31] (Complete, Contact, Incomplete types) and then was compared with those reported in the previous literature (Table 2) $[1,4,5,7,10,16,20,22,28-31,35$, 45, 47, 49-51].

Radiographical data reporting the morphological presentation of CCF based on their laterality are collected from the CT scans/angiograms and lateral view radiographs. The CCF observed in present study radiographs had only complete morphological forms with a bilateral frequency of $2 \%$ and a unilateral frequency of $4 \%$ specimens, respectively. This frequency observed in the present study was slightly higher than that reported for unilateral complete CCF in United Kingdom population (Table 3) [3, 8, 14, 22, 25, 34, 36, 40-42, 46, 54, 55].

The data on morphological types of CCF as per the classification given by Keyes [31] varies similarly in different types of populations being reported over nine decades. Of the three types, the incomplete variety (type III) or the dangerous type is the most common followed by the complete (type I), and then the contact type (type II) (Table 2). Keyes [31] reported the frequency of incomplete CCF to be $19.1 \%$ in Caucasian Americans, while the same was observed to be as high as $36.6 \%$ by Natsis et al. [45] in the Cau- 
Table 1. Comparing the prevalence of caroticoclinoid foramen based on their laterality of occurrence observed in present study with those reported in literature

\begin{tabular}{|c|c|c|c|c|c|c|}
\hline \multirow[t]{2}{*}{ Study } & \multirow[t]{2}{*}{ Population/Region } & \multirow{2}{*}{$\begin{array}{l}\text { Number } \\
\text { of skulls }\end{array}$} & \multicolumn{3}{|c|}{ Caroticoclinoid foramen [n (\%)] } & \multirow{2}{*}{$\begin{array}{c}\text { Sella turcica } \\
\text { bridge }\end{array}$} \\
\hline & & & Unilateral & Bilateral & Total & \\
\hline Keyes (1935) [31] & Caucasian American & 2187 & - & - & $600(27.46 \%)$ & $189(8.68 \%)$ \\
\hline Azeredo et al. (1988) [6] & Portuguese & 270 & $6(2.22 \%)$ & $11(4.05 \%)$ & $17(6.27 \%)$ & $9(3.04 \%)$ \\
\hline Inoue et al. (1990) [28] & Caucasian American & 50 & $11(22 \%)$ & $7(14 \%)$ & $18(36 \%)$ & $2(4 \%)$ \\
\hline Cireli et al. (1990) [15] & Turkish & 50 & $3(6 \%)$ & - & $3(6 \%)$ & $1(2 \%)$ \\
\hline Deda et al. (1992) [18] & Turkish & 88 & $6(6.82 \%)$ & $7(7.95 \%)$ & $13(14.77 \%)$ & $4(4.54 \%)$ \\
\hline Gurun et al. (1994) [26] & Turkish & 198 & $16(8.08 \%)$ & $11(5.55 \%)$ & $27(13.63 \%)$ & $2(1.01 \%)$ \\
\hline Lee et al. (1997) [35] & Korean & 73 & $15.7 \%$ & $1.4 \%$ & $17.1 \%$ & - \\
\hline Erturk et al. (2004) [20] & Turkish & 171 & $41(23.98 \%)$ & $20(11.69 \%)$ & $61(35.67 \%)$ & $14(8.18 \%)$ \\
\hline Peker et al. (2006) [48] & Turkish & 80 & - & - & - & $21(26.6 \%)$ \\
\hline Skrzat et al. (2006) [53] & Polish & 80 & $7(8.75 \%)$ & $6(7.5 \%)$ & $13(16.25 \%)$ & $11(13.7 \%)$ \\
\hline Archana et al. (2010) [4] & Indian & 250 & $23(9.2 \%)$ & $7(2.8 \%)$ & $30(12 \%)$ & $55(22 \%)$ \\
\hline Desai et al. (2010) [19] & South India region & 223 & $53(23.74 \%)$ & $30(13.45 \%)$ & $83(37.19 \%)$ & - \\
\hline Boyan et al. (2011) [9] & Turkish & 34 & - & - & $4(11.8 \%)$ & - \\
\hline Kolagi et al. (2011) [33] & South India region & 112 & $6(5.35 \%)$ & 3 & - & $9(8.04 \%)$ \\
\hline Aggarwal et al. (2011) [1] & Western India & 70 & - & - & $15.72 \%$ & - \\
\hline Freire et al. (2011) [23] & Brazilian & 80 & $7(8.75 \%)$ & $2(2.5 \%)$ & $5(6.25 \%)$ & - \\
\hline Fernandez-Miranda et al. (2012) [22] & Caucasian American & 50 & $10(20 \%)$ & $3(6 \%)$ & $13(26 \%)$ & - \\
\hline Kanjiya et al. (2012) [29] & Gujarat region & 200 & $11(6.5 \%)$ & $18(9 \%)$ & $29(14.5 \%)$ & $15(7.5 \%)$ \\
\hline Kapur et al. (2012) [30] & Bosnian & 200 & $19(9.25 \%)$ & $15(7.5 \%)$ & $33(16.5 \%)$ & $13(6.5 \%)$ \\
\hline Magadum et al. (2012) [37] & South India region & 50 & $3(6 \%)$ & - & $3(6 \%)$ & - \\
\hline Shaikh et al. (2013) [51] & Western India & 100 & $10(10 \%)$ & $14(14 \%)$ & $24(24 \%)$ & - \\
\hline Archana et al. (2013) [5] & South India region & 50 & $1(2 \%)$ & $1(2 \%)$ & $2(4 \%)$ & - \\
\hline Bansode et al. (2017) [7] & South India region & 35 & $2(5.75 \%)$ & $5(14.2 \%)$ & $7(20 \%)$ & - \\
\hline Purohit and Singh (2018) [49] & Gujarat region & 200 & $15(7.5 \%)$ & $6(3 \%)$ & $21(10.5 \%)$ & $4(2 \%)$ \\
\hline Natsis et al. (2018) [45] & Greece & 123 & $39(31.7 \%)$ & $35(28.4 \%)$ & $74(60.1 \%)$ & $24(19.5 \%)$ \\
\hline Sharma et al. (2018) [50] & Hamann-Todd Osteological collection & 2726 & - & - & $1854(68 \%)$ & $224(8 \%)$ \\
\hline Caucasian* & & 2960 & $92(3.1 \%)$ & $77(2.6 \%)$ & $768(25.9 \%)$ & $248(8.5 \%)$ \\
\hline Turkish population** & & 621 & $66(10.6 \%)$ & $38(6.1 \%)$ & $145(23.3 \%)$ & $42(6.7 \%)$ \\
\hline South India region ${ }^{* * *}$ & & 470 & $65(13.89 \%)$ & $39(8.3 \%)$ & $99(21.06 \%)$ & $9(1.91 \%)$ \\
\hline Gujrat region ${ }^{* * *}$ & & 400 & $26(6.5 \%)$ & $24(6 \%)$ & $50(12.5 \%)$ & $21(5.25 \%)$ \\
\hline Present study & Bihar region & 100 & $7(7 \%)$ & $2(2 \%)$ & $9(9 \%)$ & $1(1 \%)$ \\
\hline
\end{tabular}

*Average results presented for the Caucasian population from Keyes (1935), Azeredo et al. (1988), Inoue et al. (1990), Kapur et al. (2012), Skrzat et al. (2012), and Natsis et al. (2018)

${ }^{* *}$ Average results presented for Turkish population from Cireli et al. (1990), Deda et al. (1992), Gurun et al. (1994), Erturk et al. (2002), Peker et al. (2006), Bopyan et al. (2011)

${ }^{* * *}$ Average results presented for South Indian population from Desai et al. (2010), Kolagi et al. (2011), Magadum et al. (2012), Archana et al. (2013), and Bansode et al. (2017)

${ }^{* * * *}$ Average results for Gujrat region from Kanjiya et al. (2012), and Purohit and Singh (2018)

casian population of Greece. Though the frequency of incomplete variety was presented to be $46.6 \%$ in Hamann-Todd Osteological Collection by Sharma et al. [50], but the ethnicity of the collection cannot be fixed. Whenever this common variety presents with a pointed spicule it is then referred to as the dangerous type because of its ability to puncture the ICA. The next common variety, the complete CCF, can be considered as a bony distal dural ring [46]. The contact-type CCFs are rarely reported. The Hamann-Todd Osteological Collection study for CCFs by Sharma et al. [50] reported its frequency in $2.75 \%$ samples. Becktor et al. [8] in their cephalometric radiograph study had presented the contact and incomplete STB as a common variety (type B in the study), the STB is responsible for converting the space between the 
Table 2. Comparing the prevalence of caroticoclinoid foramen based on their morphology as observed in present study with those reported in literature

\begin{tabular}{|c|c|c|c|c|c|}
\hline \multirow[t]{2}{*}{ Study } & \multirow[t]{2}{*}{ Population/Region } & \multirow{2}{*}{$\begin{array}{l}\text { Number } \\
\text { of skulls }\end{array}$} & \multicolumn{3}{|c|}{ Caroticoclinoid foramen [n (\%)] } \\
\hline & & & Incomplete & Contact & Complete \\
\hline Keyes (1935) [31] & Caucasian American & 2187 & $418(19.15 \%)$ & 0 & $155(7.08 \%)$ \\
\hline Inoue T et al. (1990) [28] & Caucasian American & 50 & $16(32 \%)$ & 0 & $1(2 \%)$ \\
\hline Lee et al. (1997) [35] & Korean & 73 & $8(11.60 \%)$ & 0 & $3(4.10 \%)$ \\
\hline Erturk et al. (2004) [20] & Turkish & 171 & $25(14.91 \%)$ & 0 & $6(4.09 \%)$ \\
\hline Ozdugmus et al. (2003) [47] & Turkish & 50 & 0 & 0 & $3(6 \%)$ \\
\hline Archana et al. (2010) [4] & Indian & 250 & $17(6.8 \%)$ & 0 & $9(3.6 \%)$ \\
\hline Aggarwal et al. (2011) [1] & Western India & 70 & $9(12.8 \%)$ & 0 & $2(2.8 \%)$ \\
\hline Kanjiya et al. (2012) [29] & Gujarat region & 200 & $5(2.5 \%)$ & 0 & $16(8 \%)$ \\
\hline Fernandez-Miranda et al. (2012) [22] & Caucasian American & 50 & - & - & $16(32 \%)$ \\
\hline Kapur et al. (2012) [30] & Bosnian & 200 & $19(9.5 \%)$ & 0 & $9(4.5 \%)$ \\
\hline Shaikh et al. (2013) [51] & Western India & 100 & $16(16 \%)$ & 0 & $4(4 \%)$ \\
\hline Archana et al. (2013) [5] & South India region & 50 & $1(2 \%)$ & 0 & $1(2 \%)$ \\
\hline Dagtekin et al. (2014) [16] & Turkish & 40 & 0 & 0 & $2(5 \%)$ \\
\hline Brahmbhatt et al. (2015) [10] & Gujrat region & 50 & 0 & 0 & $1(2 \%)$ \\
\hline Bansode et al. (2017) [7] & South India region & 35 & $3(8.5 \%)$ & 0 & $2(5.7 \%)$ \\
\hline Purohit and Singh (2018) [49] & Gujarat region & 200 & $10(5.0 \%)$ & 0 & $11(5.5 \%)$ \\
\hline Natsis et al. (2018) [45] & Greece & 123 & $45(36.6 \%)$ & 0 & $29(23.6 \%)$ \\
\hline Sharma et al. (2018) [50] & Hamann-Todd Osteological collection & 2726 & $1275(46.6 \%)$ & $75(2.75 \%)$ & $504(18.48 \%)$ \\
\hline Caucasian* & & 2745 & $552(20.4 \%)$ & 0 & $226(8.23 \%)$ \\
\hline Turkish population** & & 261 & $25(9.5 \%)$ & 0 & $11(4.2 \%)$ \\
\hline South India region*** & & 85 & $4(4.7 \%)$ & 0 & $3(3.5 \%)$ \\
\hline Gujrat region ${ }^{* * * *}$ & & 450 & $15(3.3 \%)$ & 0 & $28(6.2 \%)$ \\
\hline Present study (2021) & Bihar region & 100 & $7(7 \%)$ & 0 & $2(2 \%)$ \\
\hline
\end{tabular}

${ }^{*}$ Average results presented for the Caucasian population from Keyes (1935), Inoue et al. (1990), Leonardi et al. (2006), Kapur et al. (2012), and Natsis et al. (2018)

${ }^{* *}$ Average results presented for Turkish population from Erturk et al. (2002), Ozdogmus et al. (2003), and Dagtekin et al. (2014)

${ }^{* * *}$ Average results presented for South Indian population from Archana et al. (2013), and Bansode et al. (2017)

${ }^{* * * *}$ Average results for Gujrat region from Kanjiya et al. (2012), Brahmbhatt et al. (2015), and Purohit and Singh (2018)

clinoid processes into a foramen. Ota et al. [46] mentioned that it is difficult to distinguish between the contact and incomplete variety of CCF intraoperatively and on preoperative computed tomography (CT), forcing them to classify the CCFs into two varieties only. Such reasons add to the limited reporting of the contact type CCF. Though Suprasanna et al. [54] reported the frequency of the contact variety CCF as $9.2 \%$ in a CT angiography study of south Indian population. The report included $1.8 \%$ frequency for bilateral contact variety CCF and $5.5 \%$ frequency for unilateral presence of contact variety CCF (Table 3).

The unilateral CCF are more frequently observed than the bilateral ones in dry skull data reported in literature from different populations (Table 1). The present study too observed a three times higher frequency of the unilateral CCF. Radiographic data from lateral view cephalometric studies, CT angiograms, and scans of head region presented with observations similar to the dry skull data regarding laterality of CCF, with the exception of the tomographic study data by Touska et al. [55]. They reported higher proportions of bilateral CCF (10.1\%) in Caucasians of United Kingdom (Table 3).

Many of the radiological studies based on the ossification of the ICL or CCL have analysed the association of the ligamentous ossification with age and sex $[14,25,36,54,55]$. Most of these studies have reported no significant association for the ossification of ICL or CCL in either of the genders $[14,25,36$, $54,55]$. A positive correlation between age and ICL or CCL ossification was reported by Cederberg et al. [14] and Leonardi et al. [36], whereas Suprasanna et al. [54], Gibelli et al. [25], and Touska et al. [55] 
Table 3. Comparing the radiological prevalence of caroticoclinoid foramen based on their laterality and morphology as observed in present study with those reported in literature

\begin{tabular}{|c|c|c|c|c|c|c|c|}
\hline \multirow[t]{2}{*}{ Study } & \multirow{2}{*}{$\begin{array}{l}\text { Population/ } \\
\text { /Region }\end{array}$} & \multirow[t]{2}{*}{ Sample size (n) } & \multirow{2}{*}{$\begin{array}{c}\text { Age } \\
\text { range } \\
\text { [years] }\end{array}$} & \multirow{2}{*}{$\begin{array}{l}\text { Gender } \\
\text { distribu- } \\
\text { tion }\end{array}$} & \multicolumn{3}{|c|}{ Caroticoclinoid foramen [n (\%)] } \\
\hline & & & & & Incomplete & Complete & Contact \\
\hline Becktor et al. (2000) [8] & Denmark & $\begin{array}{l}177 \text { lateral view cepha- } \\
\text { lometric radiographs }\end{array}$ & - & - & - & $33(18.6 \%)$ & - \\
\hline $\begin{array}{l}\text { Cederberg et al. } \\
\text { (2003) [14] }\end{array}$ & $\begin{array}{l}\text { Caucasian } \\
\text { American }\end{array}$ & $\begin{array}{l}255 \text { lateral view cepha- } \\
\text { lometric radiographs }\end{array}$ & $8-76$ & $\begin{array}{l}M=114 \\
F=141\end{array}$ & $185(72.5 \%)$ & $21(8.2 \%)$ & - \\
\hline $\begin{array}{l}\text { Leonardi et al. } \\
\text { (2006) [36] }\end{array}$ & Italian & $\begin{array}{l}135 \text { lateral view cepha- } \\
\text { lometric radiographs }\end{array}$ & $8-16$ & - & $54(40 \%)$ & $16(11.9 \%)$ & - \\
\hline Alkofide (2007) [3] & $\begin{array}{l}\text { Saudi } \\
\text { Arabian }\end{array}$ & 180 cephalograms & $10-26$ & $\begin{array}{l}M=90 \\
F=90\end{array}$ & - & $2(1.1 \%)$ & - \\
\hline $\begin{array}{l}\text { Marsan and Oztas } \\
(2009) \text { [40] }\end{array}$ & Turkish & 118 cephalograms & $21-32$ & $F=118$ & - & $14(11.86 \%)$ & - \\
\hline $\begin{array}{l}\text { Meyer-Marcotty et al. } \\
\text { (2010) [41] }\end{array}$ & German & 400 cephalograms & $16-34$ & - & - & $56(14 \%)$ & - \\
\hline $\begin{array}{l}\text { Fernandez-Miranda et al. } \\
\text { (2012) [22] }\end{array}$ & $\begin{array}{l}\text { Caucasian } \\
\text { American }\end{array}$ & $100 \mathrm{CT}$ angiograms & - & - & - & $\begin{array}{c}\mathrm{U} / \mathrm{L}=20(20 \%) ; \\
\mathrm{B} / \mathrm{L}=6(6 \%)\end{array}$ & - \\
\hline Kucia et al. (2014) [34] & Polish & $\begin{array}{l}322 \text { lateral view cepha- } \\
\text { lometric radiographs }\end{array}$ & $9-16$ & - & $22(6.8 \%)$ & $16(4.9 \%)$ & - \\
\hline Ota et al. (2015) [46] & Japan & $\begin{array}{l}72 \mathrm{CT} \text { angiograms for } \\
\text { para-clinoid aneurysm }\end{array}$ & $31-78$ & $\begin{array}{l}M=8 \\
F=64\end{array}$ & $9(6.25 \%)$ & $9(6.25 \%)$ & - \\
\hline Miller et al. (2017) [42] & $\begin{array}{l}\text { Caucasian } \\
\text { American }\end{array}$ & 150 maxillofacial CT & $31-68$ & $\begin{array}{l}M=75 \\
F=75\end{array}$ & --- & $63(42 \%)$ & - \\
\hline $\begin{array}{l}\text { Suprasanna et al. } \\
\text { (2017) [54] }\end{array}$ & South India & $\begin{array}{l}54 \mathrm{CT} \text { cerebral angiog- } \\
\text { raphy studies showing } \\
\text { para-clinoid aneurysms }\end{array}$ & $18-70$ & $\begin{array}{c}M=24 \\
F=30\end{array}$ & $\begin{array}{c}11(20.37 \%) \\
\mathrm{U} / \mathrm{L}=7(12.96 \%) ; \\
\mathrm{B} / \mathrm{L}=2(3.7 \%)\end{array}$ & $\begin{array}{c}8(14.8 \%) \\
\mathrm{U} / \mathrm{L}=4(7.4 \%) ; \\
\mathrm{B} / \mathrm{L}=2(3.7 \%)\end{array}$ & $\begin{array}{c}5(9.2 \%) \\
\mathrm{U} / \mathrm{L}=3(5.5 \%) ; \\
\mathrm{B} / \mathrm{L}=1(1.8 \%)\end{array}$ \\
\hline Gibelli et al. (2018) [25] & Italian & 300 CT head scans & 18-99 & $\begin{array}{c}M=150 \\
F=150\end{array}$ & - & $26(8.7 \%)$ & - \\
\hline Touska et al. (2019) [55] & $\begin{array}{l}\text { United } \\
\text { Kingdom }\end{array}$ & 240 CT studies & $6-80$ & $\begin{array}{c}M=119 \\
F=121\end{array}$ & $10(4.1 \%)$ & $15(6.2 \%)$ & - \\
\hline Present study (2021) & Bihar & $\begin{array}{l}50 \text { lateral view radio- } \\
\text { graphs of the head }\end{array}$ & $12-73$ & $\begin{array}{l}M=25 \\
F=25\end{array}$ & $2(4 \%)[\mathrm{U} / \mathrm{L}]$ & $1(2 \%)[B / L]$ & - \\
\hline
\end{tabular}

$\mathrm{B} / \mathrm{L}$ - bileteral; $\mathrm{CT}$ — computed tomography; $\mathrm{F}$ - female; $\mathrm{M}$ - male; $\mathrm{U} / \mathrm{L}$ - unilateral

mentioned that no significant correlation was found between the entities.

Most of the reported data on CCF is mainly concerned with its frequency in different populations as well as the effects it possesses on the nearby neurovascular structures. The dimensions of CCF are merely documented, and if so, that too only for the complete ones. The vertical diameter of the complete foramen on either side for the present study data is higher than that reported in the literature, while that for the antero-posterior (AP) diameter is lesser than that reported by Freire et al. [23] and Ozdugmus et al. [47] on either side. The vertical diameter measurements for incomplete foramina were not found in the literature, therefore couldn't be compared with the present study findings (Table 4) $[23,38,47]$. The variation in dimensions of CCF could help in predicting the mor- phological changes it causes to the clinoidal segment of the ICA [17]. Also, the CCF's metric data could be used to advantage in cases where it becomes difficult to distinguish between the varieties of the CCF, as was explained by Ota et al. [46]. These could be vital for neurosurgeons as the measurements could be obtained preoperatively from the digital radiographs or CT scans.

The embryological development of sphenoid bone in mammal occurs from two components: first, the basi-post-sphenoid and the orbito-sphenoid, being derived from cephalic mesoderm, and second, the basi-pre-sphenoid and the ali-sphenoid from neural crest cells. The two primordia have different genetic control which adds to their heterogeneity [13]. The literature cites numerous evidences explaining the development of anomalous structure from the neural 
Table 4. Comparing reported data of foraminal parameters with those of present study

\begin{tabular}{|c|c|c|c|c|c|c|}
\hline & \multicolumn{6}{|c|}{ Measurements of caroticoclinoid foramen [mm] } \\
\hline & \multicolumn{3}{|c|}{ RIGHT } & \multicolumn{3}{|c|}{ LEFT } \\
\hline & \multicolumn{2}{|c|}{ Complete } & \multirow{2}{*}{$\begin{array}{c}\text { Incomplete } \\
\text { Vertical }\end{array}$} & \multicolumn{2}{|c|}{ Complete } & \multirow{2}{*}{$\frac{\text { Incomplete }}{\text { Vertical }}$} \\
\hline & AP & Vertical & & AP & Vertical & \\
\hline Ozdogmus et al. (2003) [47] & 5.14 & - & - & 5.25 & - & - \\
\hline Freire et al. (2011) [23] & 5.23 & - & - & 5.23 & - & - \\
\hline Mallik and Sawant (2015) [38] & 4.01 & 3.64 & - & 4.12 & 3.6 & 一 \\
\hline Present study (2021) & 4.06 & 4.51 & 4.48 & 5.15 & 4.14 & 4.19 \\
\hline
\end{tabular}

$\mathrm{AP}$ - antero-posterior

crest, such as cleft palate, palatal displacement of canines, and neck skeletal elements in cases of ponticulus posticus [25]. This association of the neural crest cells with anomalies might also explain the ectopic ossification of CCL as a developmental anomaly.

The ectopic calcification of the CCLs, which are soft tissue elements, can also be a part of genetic syndromes such as Gorlin-Goltz syndrome, clinically known as Nevoid basal cell carcinoma syndrome (NBCCS) [39] or can be caused due to mutations in genes preventing mineralisation (osteopontin or matrix Gla protein gene) [43, 52].

One of the protected structures underneath the dural fold or ligaments between the clinoid processes is ICA, which at the termination of carotid sulcus passes through an osseo-ligamentous opening bounded superiorly by the ACP, postero-inferiorly by the MCP, anteriorly by the lateral edge of tuberculum sella, and postero-superiorly by the CCL between the two processes [21]. Clinically, the ossified CCL can present with severe headache due to traction on the ICA [47], and radiographically it may be misdiagnosed as a para-posterior communicating arterial aneurysm on CT angiography [27]. In conditions requiring surgical exposure of ICA and cavernous sinuses, such as clinoidal segment aneurysm or in removal of central skull base tumour (skull base meningiomas, craniopharyngiomas, supra-sellar extended pituitary adenomas), the ossified ligament could warrant excessive manipulation and drilling during anterior clinoidectomy, thus may lead to damage or rupture of the ICA [50]. In endoscopic procedures, the endonasal approach to the pituitary gland can be complicated due to the ossified CCL as it obscures the MCP presentation which acts as a landmark for the anteromedial dome of cavernous sinus and for the progression of ICA from its clinoidal segment to its cavernous part [22]. To diagnose such clinical scenarios, or to clarify the radiographic confusion, and to foresee the surgical complications presented by the CCF, it is mandatory to have the pertinent knowledge and awareness regarding the occurrence and frequency of the CCF formed due to the ossified CCL.

The clinical implications and intra-op surgical complications of CCF are mainly due to ossification of the CCL which renders the foramen unyielding to the underlying structures and hinders their surgical exposure [44]. Various researchers have tried to associate this ectopic ossification with endocrinological disorders [48], infectious diseases [12, 25], cranio-facial deviations [8], ageing [25, 45], and developmental anomaly [32]. While the literature nullifies the role of endocrinological disorders and infectious diseases in the aetiology of the ossified ligament, it does provide contradicting evidence regarding the role played by ageing in the same where some authors have reported ectopic ossification of the CCL as an age-related change $[14,36]$ while others have refuted the same with evidence $[25,45,54,55]$. Also, there have been a few logical scientific explanations (but no experimental proof) indicating that the complex embryology [13], and genetics [25, 43, 52] can play a crucial role in the aetiopathogenesis of CCF.

The present study authors in one of their previous reports have mentioned the unique finding where the ICF was divided into two foramina by an osseous bar between the MCP and the midpoint of the right lateral border of the dorsum sella (Figs. 2B; 3) [44]. The foramen beneath the osseous bar was supposed to be formed around inferior inter-cavernous sinus, which may pose same radiological and intra-op surgical complications as have been discussed for CCF. Similar finding had been previously reported by Galdames et al. [24] on the left side in an osteological case report but didn't provide any theories about the finding. Localised compression of the inferior inter-cavernous 
sinus due to the unyielding foramen around it can be viewed as dilation on sagittal T1-weighted magnetic resonance imaging images, a false positive radiological sign for intracranial hypotension [2].

\section{CONCLUSIONS}

Intricate knowledge of the CCF is of paramount importance in treatment of clinoidal segment aneurysm of ICA, arterio-venous malformation, and while approaching the central skull base tumours. Topographically, CCF is crucial because of its vicinity with sphenoidal sinus, cavernous sinus, and pituitary gland. The frequency of CCF in the present study population of Bihar was much lesser than that of the Caucasian, Turkish and other Asian populations. However, the variation in frequency of different morphological types of CCF was observed to be the same across populations. Where the incomplete type of CCF was the most common variety followed by the complete and contact type. The difficulty to distinguish the contact type from the incomplete type on the preoperative CT scans or during operative procedures and being classified together with the incomplete type are a few reasons for the meagre reporting of the contact type. The CCF was observed to be more prevalent as a unilateral entity in both the dry skull and radiological data across populations. The variations in CCF's metric data could help in predicting the morphological changes it causes to the clinoidal segment of the ICA, as well as in distinguishing its varieties. The frequency of CCF depends on various factors such as age, embryology, and genetics. The association of ageing with the ossification of CCL has contradictory evidence in literature, while the embryological theory of sphenoid bone formation from different primordia does explain the ossification as a developmental anomaly. The pre-op radiological examination of the head helps in confirming the extent and morphology of the ligamentous calcification which in turn prevents surgical complications, misinterpretation of para-posterior communicating arterial aneurysm on CT angiography, and intracranial hypotension on sagittal T1-weighted magnetic resonance imaging images. The present study in Bihar region needs more data for both the dry skull and radiological samples, to be compared comprehensively with populations having large data base. Data of different parameters of the CCF along with the points to measure them on radiological entities would help the neurosurgeons to better utilize the morphometric aspect of the fo- ramina during surgical procedures. As the sensitivity of CT scans in distinguishing the varieties of CCF has emerged as an issue, it provides the scope of further studies on the entity.

\section{Acknowledgements}

We are grateful to all the technical staff who contributed to all protocol/project development, data collection or management, data analysis of the study. We also thank all the residents and faculty members of Department of Anatomy and Radiodiagnosis of All India Institute of Medical Science Patna.

\section{Conflict of interest: None declared}

\section{REFERENCES}

1. Aggrawal B, Gupta M, Kumar H. Ossified caroticoclinoid ligament of sphenoid bone. Bombay Hosp J. 2011; 53(4): 743-746.

2. Alcaide-Leon P, López-Rueda A, Coblentz A, et al. Prominent Inferior Intercavernous Sinus on Sagittal T1-Weighted Images: A Sign of Intracranial Hypotension. AJR Am J Roentgenol. 2016; 206(4): 817-822, doi: 10.2214/ AJR.15.14872, indexed in Pubmed: 27003051.

3. Alkofide EA. The shape and size of the sella turcica in skeletal Class I, Class II, and Class III Saudi subjects. Eur J Orthod. 2007; 29(5): 457-463, doi: 10.1093/ejo/cjm049, indexed in Pubmed: 17693429.

4. Archana R, Anita R, Jyoti $C$, et al. Incidence of osseous interclinoid bars in Indian population. Surg Radiol Anat. 2010; 32(4): 383-387, doi: 10.1007/s00276-009-0582-z, indexed in Pubmed: 19862467.

5. Archana BJ, Shivaleela C, Kumar GV, et al. An osteological study of incidence, morphometry, and clinical correlations of carotico-clinoid foramen in dried adult human skulls. RJPBCS. 2013; 4(3): 347-352.

6. Azeredo RA, Liberti EA, Watanabe IS. Anatomical variations of the clinoid process of the human sphenoid bone. Arq Cent Estud Curso Odontol Univ Fed Minas Gerais. 1988; 25-26: 9-11.

7. Bansode S, P D, Vinila B, et al. Study of incidence of the carotico-clinoid foramen in the south Indian dry adult skulls: a cross sectional study. Int J Anat Res. 2017; 5(3.1): 4051-4055, doi: 10.16965/ijar.2017.247.

8. Becktor JP, Einersen S, Kjaer I. A sella turcica bridge in subjects with severe craniofacial deviations. Eur J Orthod. 2000; 22(1): 69-74, doi: 10.1093/ejo/22.1.69, indexed in Pubmed: 10721247.

9. Boyan N, Ozsahin E, Kizilkanat E, et al. Surgical importance of the morphometry of the anterior clinoid process, optic strut, caroticoclinoid foramen, and interclinoid osseous bridge. Neurosurgery Quarterly. 2011; 21(2): 133-136, doi: 10.1097/wnq.0b013e31820f1929.

10. Brahmbhatt RJ, Bansal M, Mehta $C$, et al. Prevalence and dimensions of complete sella turcica bridges and its clinical significance. Indian J Surg. 2015; 77(Suppl 2): 299-301, doi: 10.1007/s12262-012-0800-5, indexed in Pubmed: 26730013. 
11. Camarda AJ, Deschamps C, Forest D, et al. Stylohyoid chain ossification: a discussion of etiology. Oral Surg Oral Med Oral Pathol. 1989; 67(5): 508-514, doi: 10.1016/00304220(89)90264-8, indexed in Pubmed: 2497419.

12. Carstens M. Die selladiagnostik. Fortschr Geb Rontgenostrahlen. 1949; 71: 257-272.

13. Catala M. [Embryology of the sphenoid bone]. J Neuroradiol. 2003; 30(4): 196-200, indexed in Pubmed: 14566186.

14. Cederberg RA, Benson BW, Nunn M, et al. Calcification of the interclinoid and petroclinoid ligaments of sella turcica: a radiographic study of the prevalence. Orthod Craniofac Res. 2003; 6(4): 227-232, doi: 10.1034/j.16000544.2003.00243.x, indexed in Pubmed: 14606526.

15. Cireli $E$, Ustun EE, Yurtseven $M$, et al. Fossa sella turcica varyasyonlarının degerlendirilmesi I: Morfolojik ve antropolojik kriterlere gre. Ege Tıp Dergisi. 1990; 29: 364-367.

16. Dagtekin A, Avci E, Uzmansel $D$, et al. Microsurgical anatomy and variations of the anterior clinoid process. Turk Neurosurg. 2014; 24(4): 484-493, doi: 10.5137/10195149.JTN.8738-13.1, indexed in Pubmed: 25050671.

17. Das S, Suri R, Kapur V. Ossification of caroticoclinoid ligament and its clinical importance in skull-based surgery. Sao Paulo Med J. 2007; 125(6): 351-353, doi: 10.1590/s151631802007000600009 , indexed in Pubmed: 18317606.

18. Deda H, Tekdemir I, Kaplan A, et al. Sinus cavernosus mikro anatomisi (bölüm 1) kemik yaplar ve varyasyonlar. J Faculty Med Univ Ankara. 1992; 45: 477-486.

19. Desai SD, Sreepadma S. Study of caroticoclinoid foramen in dry human skulls of North Interior Karnataka. NJBMS. 2010; 1: 60-64.

20. Erturk M, Kayalioglu G, Govsa F. Anatomy of the clinoidal region with special emphasis on the caroticoclinoid foramen and interclinoid osseous bridge in a recent Turkish population. Neurosurg Rev. 2004; 27(1): 22-26, doi: 10.1007/s10143-003-0265-x, indexed in Pubmed: 14634836.

21. Evans BT. Infratemporal and pterygopalatine fossae and temporomandibular joint. In: Standring S, Anand N (eds.) Gray's Anatomy: The Anatomical Basis of Clinical Practice. Elsevier, Philadelphia 2016: 534-555.

22. Fernandez-Miranda JC, Tormenti M, Latorre F, et al. Endoscopic endonasal middle clinoidectomy: anatomic, radiological, and technical note. Neurosurgery. 2012; 71(2 Suppl): 233-239, doi: 10.1227/NEU.0b013e3182690b6b, indexed in Pubmed: 22806082.

23. Freire AR, Rossi A, Prado FB, et al. Caroticoclinoid foramen in human skulls: incidence, morphometry and its clinical implications. Int J Morphol. 2011; 29(2): 427-431, doi: 10.4067/s0717-95022011000200021.

24. Galdames IS, Matamala DZ, Smith R. Ossification of the sella turcica and clinoid ligments: case report, morphological study and literature review. Int J Morphol. 2008; 26(4): 799-801, doi: 10.4067/s0717-95022008000400002.

25. Gibelli D, Cellina M, Gibelli S, et al. Sella turcica bridging and ossified carotico-clinoid ligament: Correlation with sex and age. Neuroradiol J. 2018; 31(3): 299-304, doi: 10.1177/1971400917751036, indexed in Pubmed: 29323624.

26. Gurun R, Magden O, Ertem AD. Foramen corticoclinoideum. Cerrahpasa Tıp Dergisi. 1994; 25: 685-691.
27. Gupta V, Khandelwal N, Mathuria SN, et al. Calcified interclinoid ligament: an unusual cause of misinterpretation on cerebral CT angiography. Clin Radiol. 2013; 68(7): e426-e428, doi: 10.1016/j.crad.2013.03.019, indexed in Pubmed: 23622793.

28. Inoue $T$, Rhoton AL, Theele $D$, et al. Surgical approaches to the cavernous sinus: a microsurgical study. Neurosurgery. 1990; 26(6): 903-932, doi: 10.1097/00006123199006000-00001, indexed in Pubmed: 2362670.

29. Kanjiya D. Incidence of ossified interclinoid bars in dry human skulls of Gujarat state. IJBAR. 2013; 3(12), doi: 10.7439/ijbar.v3i12.867.

30. Kapur E, Mehić A. Anatomical variations and morphometric study of the optic strut and the anterior clinoid process. Bosn J Basic Med Sci. 2012; 12(2): 88-93, doi: 10.17305/ bjbms.2012.2502, indexed in Pubmed: 22642592.

31. Keyes JEL. Observations on four thousand optic foramina in human skulls of known origin. Arch Ophthalmol. 1935 ; 13(4): 538-568, doi: 10.1001/archopht.1935.00840040026002.

32. Kjaer I. Ossification of the human fetal basicranium. J Craniofac Genet Dev Biol. 1990; 10(1): 29-38, indexed in Pubmed: 2373754.

33. Kolagi S, Herur A, Patil G, et al. Complete sella turcica bridges prevalence and dimensions. J Anat Soc India. 2011; 60(1): 22-25, doi: 10.1016/s0003-2778(11)80005-5.

34. Kucia A, Jankowski T, Siewniak $M$, et al. Sella turcica anomalies on lateral cephalometric radiographs of Polish children. Dentomaxillofac Radiol. 2014; 43(8): 20140165, doi: 10.1259/dmfr.20140165, indexed in Pubmed: 25182120.

35. Lee HY, Chung IH, Choi BY, et al. Anterior clinoid process and optic strut in Koreans. Yonsei Med J. 1997; 38(3): 151-154, doi: 10.3349/ymj.1997.38.3.151, indexed in Pubmed: 9259614.

36. Leonardi $R$, Barbato $E$, Vichi $M$, et al. A sella turcica bridge in subjects with dental anomalies. Eur J Orthod. 2006; 28(6): 580-585, doi: 10.1093/ejo/cjl032, indexed in Pubmed: 16954179 .

37. Magadum A, Jevoor P, Dixit D, et al. A study of caroticoclinoid foramen in the South Indian skulls: Incidence, morphometry, and its clinical correlations. BIOMIRROR, An Open Access Journal. 2012; 3(5): 1-3.

38. Mallik S, Santanu VG. Bilateral "carotico-clinoid foramen" with "sella turcica bridge": a case report. Anat Physiol. 2015; 5(S5), doi: 10.4172/2161-0940.s5-006.

39. Manjima S, Naik Z, Keluskar V, et al. Multiple jaw cysts-unveiling the Gorlin-Goltz syndrome. Contemp Clin Dent. 2015; 6(Suppl 1): S102-S105, doi: 10.4103/0976237X.152959, indexed in Pubmed: 25821359.

40. Marsan G, Oztas E. Incidence of bridging and dimensions of sella turcica in Class I and Class III Turkish adult female patients. World J Orthod. 2009; 2: 99-103.

41. Meyer-Marcotty P, Reuther T, Stellzig-Eisenhauer A. Bridging of the sella turcica in skeletal Class III subjects. Eur J Orthod. 2010; 32(2): 148-153, doi: 10.1093/ejo/cjp081, indexed in Pubmed: 19752019.

42. Miller C, Chamoun R, Beahm D. Morphometric analysis of the middle clinoid process using maxillofacial computed tomography scans. Oper Neurosurg (Hagerstown). 2017; 
13(1): 124-130, doi: 10.1227/NEU.0000000000001310, indexed in Pubmed: 28931257.

43. Murshed M, Schinke T, McKee MD, et al. Extracellular matrix mineralization is regulated locally; different roles of two gla-containing proteins. J Cell Biol. 2004; 165(5): 625-630, doi: 10.1083/jcb.200402046, indexed in Pubmed: 15184399.

44. Narayan RK, Asghar A, Ghosh SK. Ossification around intercavernous sinus: an osteological finding that can complicate trans-sphenoidal surgery. Morphologie. 2020; 104(347): 280-286, doi: 10.1016/j.morpho.2020.06.005, indexed in Pubmed: 32646846.

45. Natsis K, Piagkou M, Lazaridis N, et al. Incidence and morphometry of sellar bridges and related foramina in dry skulls: Their significance in middle cranial fossa surgery. J Craniomaxillofac Surg. 2018; 46(4): 635-644, doi: 10.1016/j.jcms.2018.01.008, indexed in Pubmed: 29534911.

46. Ota N, Tanikawa R, Miyazaki T, et al. Surgical microanatomy of the anterior clinoid process for paraclinoid aneurysm surgery and efficient modification of extradural anterior clinoidectomy. World Neurosurg. 2015; 83(4): 635-643, doi: 10.1016/j.wneu.2014.12.014, indexed in Pubmed: 25527880.

47. Ozdoğmuş O, Saka E, Tulay $C$, et al. The anatomy of the carotico-clinoid foramen and its relation with the internal carotid artery. Surg Radiol Anat. 2003; 25(3-4): 241-246, doi: 10.1007/s00276-003-0111-4, indexed in Pubmed: 12748816.

48. Peker T, Anil A, Gülekon N, et al. The incidence and types of sella and sphenopetrous bridges. Neurosurg Rev. 2006; 29(3): 219-223, doi: 10.1007/s10143-006-0018-8, indexed in Pubmed: 16528575.
49. Purohit BJ, Singh PR. Incidence, anatomy and clinical significance of carotico-clinoid foramen and interclinoid osseous bridge in human skulls in gujarat region. Int J Anat Radiol Surg. 2018; 7(2): 33-37, doi: 10.7860/ IJARS/2018/35641:2391.

50. Sharma A, Rieth GE, Tanenbaum JE, et al. A morphometric survey of the parasellar region in more than 2700 skulls: emphasis on the middle clinoid process variants and implications in endoscopic and microsurgical approaches. J Neurosurg. 2018; 129(1): 60-70, doi: 10.3171/2017.2.JNS162114, indexed in Pubmed: 28799880.

51. Shaikh S, Ukey R, Kawale D, et al. Study of carotico-clinoid foramen in dry human skull of aurangabad district. Int J Basic Med Sci. 2013; 5(3): 148-154.

52. Steitz SA, Speer MY, McKee MD, et al. Osteopontin inhibits mineral deposition and promotes regression of ectopic calcification. Am J Pathol. 2002; 161(6): 2035-2046, doi: 10.1016/S0002-9440(10)64482-3, indexed in Pubmed: 12466120

53. Skrzat J, Szewczyk R, Walocha J. The ossified interclinoid ligament. Folia Morphol. 2006; 65(3): 242-245, indexed in Pubmed: 16988924.

54. Suprasanna K, Kumar A. Surgically relevant bony anatomical variations in paraclinoid aneurysms-three-dimensional multi-detector row computed tomography-based study. J Neurosci Rural Pract. 2019; 8(3): 330-334, doi: 10.4103/ jnrp.jnrp_416_16.

55. Touska P, Hasso S, Oztek A, et al. Skull base ligamentous mineralisation: evaluation using computed tomography and a review of the clinical relevance. Insights Imaging. 2019; 10(1): 55, doi: 10.1186/s13244-019-0740-8, indexed in Pubmed: 31115710. 